\title{
РОЛЬ КРУПНОГО БИЗНЕСА В ФОРМИРОВАНИИ РЕГИОНАЛЬНОЙ ПОЛИТИКИ РОССИЙСКОГО ГОСУДАРСТВА: СЫРЬЕВОЙ АСПЕКТ
}

\begin{abstract}
Аннотация: Целью проводимого в статье исследования является установление роли крупного бизнеса в формировании региональной политики российского государства. Для достижения поставленной иели необходимо решение основных задач: исследование институциональной обусловленности характера политической деятельности крупного бизнеса в современной России; рассмотрение инструментов влияния бизнеса на региональную политику и их практическое применение. Объектом исследования является региональная политика российского государства, предметом - крупный бизнес России. По результатам проведенного исследования сделаны выводы о том, что сырьевая направленность воздействия компаний, работающих в сырьевом секторе на региональную политику останется неизменной до тех пор, пока не поменяется структура российской экономики. Роль крупного бизнеса в формировании региональной политики государства, проводимой в отношении сырьевых регионов, в будущем будет зависеть от расстановки политических сил и степени консолидации путинского режима. Следовательно, сырьевые компании в своих региональных стратегиях зависимы не только от внешнеэкономической конъюнктуры, но и от внутриполитической конъюнктуры. Прогноз в отношении роли крупного бизнеса в региональной политике в будущем зависим от электоральных изиклов. Система государственного капитализма, устоявшаяся в современной России будет только укрепляться. Основные практические результаты исследования заключаются в сведении трех феноменов: крупного бизнеса, государства и сырьевых регионов, с пересечением их интересов в сфере федеральной региональной политики. Дополнительно станут понятными векторы дальнейтего изучения роли крупного бизнеса в формировании региональной политики и эффект, который будут получать от этого сырьевые регионы.
\end{abstract}

Ключевые слова: бизнес, партнерство, колониализм, экономическая политика, регион, государство, экономика, безопасность, ресурсы, национальное богатство.

Review: The goal of the study in this article is establishing the role of the large-scale business in the formation of the regional policy of the Russian state. In order to achieve this aim, it is necessary to meet the immediate goals: to study institutional prerequisites for the large-scale business political activities in the modern Russia; to evaluate the instruments of influence of business upon the regional politics and their practical application. The object of studies is regional policy of the Russian state, and the immediate object is large-scale business in Russia. Based upon the study, the author makes a conclusion that the raw-material vector of influence of the companies in the raw materials sector upon the regional politics shall remain until the structure of the Russian economy changes. The role of large-scale business in the formation of regional policy of the state towards the regions rich in raw materials in the future shall depend on the positions of political forces and 
the level of consolidation of Putin's regime. Therefore, the regional strategies of the raw materials companies depend on both the foreign economic conjuncture and the domestic conjuncture. The forecast of the large-scale business role in the regional politics in the future is dependent upon the electoral cycles. The system of state capitalism, which is formed in the modern Russia, shall be further consolidated. The main practical results of the study may be found by bringing together three phenomena: the large scale business, state and raw materials regions, the federal regional policy being the focal point of their interests. Additionally, it shall be helpful for understanding the vectors for the further studies of the large - scale businesses role in the formation of regional politics and the its effects on the regions rich in raw materials.

Keywords: business, partnership, colonialism, economic politics, region, state, economics, security, resources, national riches.

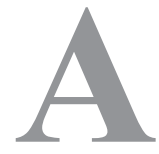

ктуальность темы роли крупного бизнеса в политических процессах, в частности аспект влияниябизнеса на региональную политику государства, обеспечиваюттри фактора: монополистический характер российской экономики, ее сырьевая специализация и близкие отношения крупного бизнеса и власти. Эти факторы, во-первых, обеспечивают крупный бизнес «структурной силой», во-вторых, ставят финпромгруппы, функционирующие в сырьевых секторах, под пристальный контроль государства. Другим факторомявляется монополизм в политической сфере и централизация всех решений по региональной политике.В 2000-е гг. мы наблюдаем тенденции на слияние экономической и политической монополии и подчинение ими сырьевой сферы и сырьевых регионов. В связи с этим необходимо выявить механизмы и характер влияния субъектов крупного бизнеса на проведение государственной региональной политики.

В экономической сфере усилилась роль общенациональных вертикально-интегрированных холдингов и госкорпораций. Региональной политике стала свойственна реализация проектов общенационального значения, спонсирование построения транспортной инфраструктуры к выгодным для бизнеса объектам. На фоне перемещения принятия стратегических решений в центр, некоторые исследователи говорят о «сворачивании» собственно региональной политики и «деполитизации» отношений центра с регионами ${ }^{1}$, превращении губернаторского корпуса в обычных чиновников, выполняющих приказ начальника «сверху», в данном случае своего «патрона»-президента РФ. В связи с этим устройство отношений центр-регионы, отношений внутри «корпорации «Государство» сами по себе стали напоминать устройство вертикально-интегрированного холдинга или финпромгруппы.

Влияние бизнеса на власть, на принятие политическими элитами стратегическихи текущих решений, на политические процессыхарактерно для любой политии. Такое влияние в каждом конкретном страновом случае проявляются по-разному, но существует оно везде.Вследствие определенной степени влиятельности крупных компаний, особенно полугосударственныхи государственных, необходимо затронуть тот факт, что они представляют групповые интересы, которые придают им импульс к политическому действию. Наиболее популярна в рассмотрении взаимодействия бизнеса и власти теория групп интересов. Рассуждения в этом ключе встречаются практически в каждом

\footnotetext{
${ }^{1}$ Гончаров Д.В. Структура территориальной политики России. Полис. № 32012
} 
диссертационном исследовании о ФПГ или бизнесе. Однако, остановимся в рамках данного исследования лишь на перечислении классиков теории групп интересов.Бэнтли, Трумэн, Олсен, Верба, Алмонд, Дюверже, Дюркгейм внесли огромный вклад в изучение интересующей нас проблематики. В этом контексте следует подчеркнуть, что крупный бизнес, как правило, является самым активным политическим актором помимо государства и, безусловно, выступает в качестве одной из активнейших группинтересов в российской социальной системе.

Объяснение переплетения интересов руководителей крупных компаний с интересами высших политиков и чиновников является очень важным моментом. Поскольку крупнейшие национальные компании являются группами интересов, им необходимы контрагенты во власти, которые проводили бы их линию. На такое взаимодействие охотно идут чиновники, которые так же входят в группы интересов (в соответствии с широкой трактовкой понятия $\left.{ }^{1}\right)$, иначе говоря, принадлежат к общим с бизнес-группами патронажноклиентельным пирамидам².

В этом может быть заложена точка соприкосновения крупного бизнеса и высшего чиновничества, т.к. их взаимодействие, скорее всего, способствует достижению их групповых интересов. Помогая друг другу в достижении своих целей, две эти группы вступают в отношения зависимости. На этом основании им выгодно иметь дело друг с другом, т. к. вступая в сотрудничество, они уменьшают собственные издержки, затрачи-

\footnotetext{
${ }^{1}$ Павроз А.В. Группы интересов и лоббизм в политике: Учебное пособие. СПб.: Изд-во С.- Петерб. ун-та, 2006.

${ }^{2}$ Henry Hale and Ivan Kurilla, Россия «двухтысячных»: Стереоскопическийвзгляд (Russia in the 200 0s: A Stereoscopic View), Planeta, 2011.
}

ваемые для достижения цели. Имея в виду то что определенные группы чаще всего выступают с более сильных позиций, их отношения можно назвать патронажно-клиентельными.Чиновники при этом взаимодействии выходят за рамки предписанного им использования власти. При выходе за рамки формальных институтов, обе стороны (бизнес и чиновники) действуют в неформальной зоне.

Расширенный подход к трактованию теории групп интересов подкрепляетсяклиентелистской концепцией, зародившейся в трудах западных советологов и развивающейся в отечественных исследованиях ${ }^{3}$. Так, в отечественный политологический дискурстеорию «клиентелизма» ввел М. Н. Афанасьев ${ }^{4}$. При рассмотрении клиентелисткого влияния на политическое функционирование крупного бизнеса нужно отдельно подчеркнуть важность ключевого для клиентелизма феномена доверия. Относительно данного феномена действует следующая логика. Во-первых, если ты кому-то доверяешь, ты не будешь лишний раз проверять информацию, поступающую от этого контрагента. Во-вторых, если ты окружен такими людьми, это значительно снижает твои информационные издержки, и они стремятся к нулю, т.е. к идеальному состоянию ${ }^{5}$.В развитых политиях именно институты призваны снижать различные издержки. В политиях с неустоявшимися институтами, к коим относится

\footnotetext{
3 RostislavTurovskyThe Representation of Business Elites in Regional Politics: Etatism, Elitism and Clientelism, // Federalism and Local Politics in Russia: Routledge. 2008

4 Афанасьев М.Н., Клиентелизм и российская государственность.—-М.: Московский общественный научный фонд, 2000

${ }^{5}$ Норт Д. Институты, институциональные изменения и функционирование экономики.-М.: Фонд экономической книги «НАЧАЛА», 1997
} 
Россия, такую функцию вместо институтов могут выполнять «свои», «проверенные» люди. Таким образом, в условиях институциональной неопределенности клиентские сети выполняют функцию восполнения недостающих или плохо функционирующих институтов, снижают высокие политические и экономические риски.

Помимо описанных выше факторов, на характер политической активности бизнес групп влияет фактор генезиса крупного бизнеса в посткоммунистическойРоссии. При смене экономического строя на новый капиталистический произошла «конвертация власти в собственность» ${ }^{1}$. Основным фактом, объединяющим политическую и бизнес-элитуРоссии, роднящим их является номенклатурное происхождение.Так, возник феномен зависимой буржуазии, отголоски которого слышны до сих пор.Огромный массив государственной собственности при зарождении «капитализма без капиталистов», как правило, либо передавался уполномоченным, либо происходило самовольное «пересаживание» чиновника в кресло бизнесмена с сохранением подконтрольных ему структур и собственности.

Непрозрачность происхождения капиталов, с одной стороны, и бюрократическая психология рантье, с другой стороны, рождаетсимбиозбизнеса и бюрократии, который приобретает клановую структуру замкнутого типа. Основой такого симбиоза служат теневые, неформальные взаимодействия, которое осуществляется по особым, сепаратным каналам. Такие отношения бизнеса и власти были названы «симбиотическими»².

\footnotetext{
${ }^{1}$ Крыштановская О.В. Российская элита и бизнес// Трансформация российской элиты: 1981-2003 гг. дис. д.с.н. 2003.

2 Зудин А. Государство и бизнес в России: эволюция взаимоотношений.— «Неприкосновенный запас», № 6
}

Таким образом, союз двух самых сильных социальных общностей (административного peсурса и бизнеса) рождает внутри кланов импульсы к наращиванию собственного экономического «веса» и удержанию своего доходного статуса, а с другой стороны, заглушает их воспоминания об «общественном благе».

Недавно для характеристики совмещения бюрократических и бизнес элит в научный оборот былвведен термин корпоративные элиты ${ }^{3}$, который подчеркивает транснациональный аспект данной проблематики. Если опустить международные тренды, фактор генезиса остается одним из наиболее показательных. Крупный бизнес в силу естественных причин и в силу специфики его происхождения в Новой России в значительной степени сохранил каналы связи с властью и остается заинтересованным субъектом политического участия, даже если не брать во внимание прочие факторы, такие как превращение крупнейших компаний в транснациональные корпорации.

Таким образом, в наши дни модель политического участия бизнеса можно назвать скорее адаптивной. Адаптируется бизнес под бюрократию. Дополнительным глубинным импульсом для складывания такой модели взаимодействия бизнеса и государства стала характерная для России политическая культура ${ }^{4}$.На подсознательном уровне со времен Древней Руси осталось сакральное восприятие власти, поэтому неудивительно, что вследствие воздействия всех вышеперечисленных институциональных факторов экономи-

(50), 2006. c. 208

${ }^{3}$ Кочетков А. П. Корпоративные элиты.- М: РОССПЭН 2012.

${ }^{4}$ Хархордин О. Основные понятия российской политики. М.: Новое литературное обозрение, 2011. 
ческий строй в России приобрел черты государственного/бюрократического капитализма ${ }^{1}$.

За период постсоветской действительности модели взаимодействия бизнеса и власти менялись неоднократно, что в целом характерно для переходных обществ с неустоявшимися институтами. Со второго срока президентства В.В. Путина эти изменения стали более плавными, по сравнению с предыдущим периодом.Однако наиболее существенным для раскрытия темы статьи является не хронологическое описание моделей взаимодействия бизнеса и власти ${ }^{2}$, но факт наличия дифференцированного отношения власти к крупному бизнесу. Так, в противовес официальному "равноудалению» крупного бизнеса 2004 г., реальные действия политической элиты демонстрировалиразное отношение к отдельным крупнейшим компаниям. С небольшими изменениями такое разделение сохраняется и в последние годы ${ }^{3}$. Крупный бизнес условно разделился на «старых» акторов, появившиеся до прихода В.В. Путина, и «новых», появившиеся при Путине ${ }^{4}$.

\footnotetext{
${ }^{1}$ Перегудов С.П. Политическая система России в мировом контексте: институты и механизмы взаимодействия. М.: РОССПЭН, 2011.

2 Зудин А.Ю. Распределение источников влияния на принятие властных решений в современной России// Элиты и общество в сравнительном измерении: сб. ст. под ред. Гаман-Голутвиной О.В.- М.: РОССПЭН, 2011.; Яковлев А. А. В поисках новой социальной базы, или Почему российская власть меняет отношение к бизнесу.// Общественные науки и современность, № 2, 2013

${ }_{3}^{3}$ Минченко консалтинг. Доклад «Политбюро 2.0 и большое правительство», август 2012 г;; Доклад «Политбюро 2.0» накануне перезагрузки элитных групп. Январь 2013 г.

${ }^{4}$ Макаркин А.В. Политико-экономические кланы современной России. М.: ЦПТ, 2003.
}

При рассмотрении различных типологий российских регионов ${ }^{5}$ во многом становится понятным выделение отдельной группы сырьевых регионов. Подразделение всей совокупности российских регионов на достаточно большое число групп (в среднем от 6 до 9) свидетельствует о том, что универсализм в принятии решений по 83 абсолютно разнымрегионам, каждый из которых имеет свою уникальную специфику, нецелесообразен. Регионы разбиваются на группы, и решения по региональной политике обоснованно принимаются для каждой группы регионов отдельно. Следовательно, действительно имеет смысл рассматриватьформирование региональной политики отдельно для группы сырьевых регионов.

В соответствии с проведенным анализом репрезентативных групп от бизнеса и от объектов региональной госполитики, мы получаем первые выводы. С вычетом Оренбургской области (старопромышленный, неперспективный регион) ${ }^{6}$ для крупного бизнеса важнытри перспективных региональных направления: 1) северное (Коми и Ненецкий $\mathrm{AO})$; 2) уральско-сибирское (ХМАО, ЯНАО, Кемеровская область) и 3) дальневосточное (Якутия, Чукотский АО и Сахалин). За северным и дальневосточным $(1,3)$ направлениями в среднесрочной перспективе во многом кроется разработка месторождений Арктического шельфа. За уральско-сибирским направлением (2) тоже прослеживаются будущие для сырьевых компаний перспективы. Однако, в настоящее время наибольшую ренту и бизнес

\footnotetext{
${ }^{5}$ Министерство регионального развития. Типология социально-экономического развития субъектов Российской Федерации. http://archive.minregion.ru/WorkItems/ NewsItem.aspx? NewsID $=492$

${ }^{6}$ Власть, бизнес, общество в регионах: неправильный треугольник/ под редакцией Н. Петрова и А. Титкова; Моск. Центр Карнеги.- М.: РОССПЭН, 2010
} 
группам и политическим элита приносят регионы именносрединного пояса (2).

Для придания бизнес-акторам собственной логики выстраивания политической стратегии рассмотрим, что бизнес может противопоставить государству, в чем его сила. Для этого вспомним концепциюструктурной власти бизнеса или власти вето Чарльза Линдблома ${ }^{1}$.Согласно этой концепции поведение бизнеса находится в прямой связи с экономической и социальной политикой государства. Бизнес в свою очередь может влиять на правительство при выработке им неблагоприятной для бизнеса политики, используя механизм бегства капитала за рубеж и снижая свою инвестиционную активность. Располагая ключевыми позициями в экономике, бизнес не просто лоббирует свои интересы, но действует как власть. Эта власть не абсолютна, но иногда она работает.Не имея возможности повлиять на президента напрямую, бизнес в настоящее время старается проводить свои интересы, не офишируя своих действий. Такие действия бизнеса (например, вывоз капитала) приносят российской экономике весьма серьезный ущерб, и уже вызвали нарекания со стороны президента, провозгласившего в своем послании Федеральному Собранию РФ деоффшоризацию российской экономики².Однако, в большинстве случаев речь идет все же о сотрудничестве. Использование государственных механизмов для наращивания влияния собственных групп интересов или включенных в пирамиду клиентов происходит в интересующей нас сфере формирования региональной политики и отношений власти

\footnotetext{
${ }^{1}$ Перегудов С. П. Политическая система России в мировом контексте: институты и механизмы взаимодействия. М.: РОССПЭН, 2011.

${ }^{2}$ Путин В. В. Послание Федеральному Собранию 2012. президент.рф.
}

с бизнесом. Например, такое сотрудничество наблюдается в области лицензирования экономической деятельности (особенно добычи полезных ископаемых), приватизации государственного имущества, работы с госзакупками, частно-государственного партнерства, совместных инвестиционных проектов ${ }^{3}$.

Надо заметить, что базовые регионы у ФПГ и государства представляют собой одни и те же территории, на которых сконцентрировано максимальное количество сырьевых ресурсов.Объяснение заключается в том, что государственный бюджет и сами политические акторыполучает максимальную ренту именно с этих регионов. По мнению автора, существует два основных источника замотивированности государства на «развитие» сырьевых территорий.

Первая причина единства интересов бизнеса и политической элиты в формировании региональной политики в отношении сырьевых территорийличный доход политической элиты и отсутствие у нее полной уверенности в своем будущем. Используя элитистский подход, будем оценивать заинтересованность государства в сырьевых регионах с точки зрениязаинтересованности в них высшей политической элиты страны. Государствои политическая элита в этом смысле будут нами отождествлены.Первая причина заинтересованности государства в развитии сырьевых регионов, по сути, состоит из двух элементов: получения высокопоставленными чиновниками сырьевой ренты (политическим акторам важно «заработать» на своей должности и на своем нынешнем политическом «весе» здесь и сейчас, как можно быстрее в прямом смысле обналичить свой политический ресурс); неуверенности политического

\footnotetext{
${ }^{3}$ RostislavTurovskyThe Representation of Business Elites in Regional Politics: Etatism, Elitism and Clientelism, // Federalism and Local Politics in Russia: Routledge. 2008
} 
класса в завтрашнем дне (существование в условиях патрональной избирательной системы, внутриэлитная деконсолидация и межклановая борьба).

Второй мотив - государственная безопасность и сохранение суверенитета. Эта причина так же подразумевает интересы политических акторов, хотя она в большей степени полезна для всего государства, нежели первая. Государственная национальная безопасность, несомненно, имеет больше общего с понятием «общего блага».Тем не менее, мотивация элит в этом вопросе схожа с мотивацией относительно личного сверхвысокого дохода чиновников.

Такая позиция затрагивает все высшие уровни вертикали исполнительной власти. В том числе высшее должностное лицо в государстве. Премьер, а ныне президент В. Путин начинает свою предвыборную статью, посвященную национальной безопасности, с фразы о полезных ископаемых: «неслучайно уже сегодня раздаются голоса, что, мол, скоро «объективно»встанет вопрос о том, что национальный суверенитет не должен распространяться на ресурсы глобального значения» ${ }^{2}$ В этом же ключе Путин высказывался и ранее. Основным тезисом стала тогда опасность тотальной модернизации российской экономики. Так, чрезмерная и активная модернизация может значительно упростить структуру российской экономики. Экспорт высокотехнологичных товаров сделает Россию не менее экспортоориентированной, а зависимость от внешней конъюнктуры останется прежней. Однако, в таких заявлениях есть доля лукавства. Выгодоприобретателем сырьевой ренты являются не только граждане государства, но в большей степени высшие

\footnotetext{
${ }^{1}$ Путин В. В. Быть сильными: Гарантии национальной
} безопасности для России.- М.: Едиториал УРСС, 2012. слои элит (как экономической, так и политической).

Таким образом, рыночные ФПГ и их владельцызачастуюдействуют под давлением рынка и по его правилам, из соображений получения максимальной прибыли в максимально короткие сроки. Да, названные интересы рыночных ФПГ полностью сходятся с интересами чиновников. Однако, в интересах крупного бизнеса и высших чиновников есть существенное различие: политическая элита страны, в частности народно избираемый президент, обязаны думать не только о получении ренты и лояльности элит, но так же о своем электорате, который обеспечивает получение политического ресурса.

Для реального участия в региональной политике и достижении в ходе ее реализации своих интересов крупный бизнес может использовать три инструмента: федеральные целевые программы, государственно-частное партнерство через Инвестиционный Фонд и свободные экономические зоны.

Рассмотрим вкратце то, как бизнес использует для продвижения своих интересов федеральные целевые программы (ФЦП). Роль бизнес-групп в ФЦП часто сводится к тому, что государственные компании служат внебюджетными источниками финансирования ФЦП (например, «Газпром» и «РЖД»). Хотя для сырьевых ФПГ участие в федеральных целевых программах сводится не только к обременительным расходам, но так же к получениюстратегическихпреимуществ.

Из истории возникновения ФЦП в России известно, что первые программы были приняты для Курильских островов Сахалинской области (в 1993-2005 г.) и для Республики Саха (в 1995-2005 г.). К настоящему моменту число федеральных целевых программ значительно выросло, поэтому мы можемвыделить ряд ФЦП, затрагивающихтерри- 
тории сырьевых регионов нашей выборки. Например, ФЦП «Экономическое и социальное развитие Дальнего Востока и Забайкалья на периоддо 2013 г.», ФЦП «Социально-экономическое развитие курильских островов (Сахалинская область) на2007-15 гг.»1. Отметим, что направления остались теми же, что и изначальные, правда к ним прибавился ряд других направлений на востоке, на юге и в европейской части России.

Еще одним примером участия крупного бизнеса в региональной политике является государственно-частное партнерство, часто осуществляемое именно на базе региональных проектов. Для развития государственно-частного партнерства в сфере региональной политики в 2005 г. был создан Инвестиционный фонд РФ. Импульсом к созданию Инвестфонда стало недостаточное взаимодействие государства и бизнеса при разработке ФЦП. Финансовое участие бизнеса в проектах Инвестфонда должно было составлять $25 \%$. Сейчас за счетсовместного финансирования осуществляются проекты общегосудартсвенного значения, локализованные в регионах.В 2007 г. была проведена реформа этого института взаимодействия бизнеса и власти. В ходе реформирования было решено сделать возможным запуск региональных, а не только общегосударственных проектов, повысить долю участия бизнеса до 50\%. Кроме того, Инвестфондбыл передан из ведения Минэкономразвития в Минрегион. Этот шаг закрепил статус Инвестфонда в качестве площадки для бизнеса и государства по формированию и реализации экономического блока федеральной региональной политики. Однако, несмотря на прогресс в сотрудничестве бизнеса и го-

\footnotetext{
${ }^{1}$ Кузнецова О.В. Основы региональной политики: учебное пособие: М.: Географический факультет МГУ, 2012.
}

сударства по стратегическим проектам, федерального закона о государственно-частном партнерстве до сих пор не существует².

Проекты Инвестфонда, как правило, представляют собой объектыинфраструктуры. Основная их масса сводится к строительству железнодорожных линий к месторождениям полезных ископаемых. Однако, следует сделать ремарку: инвестпроекты распространяются далеко не только на сырьевые регионы. Важным факторомутверждения проекта помимо заинтересованности ФПГ и бюрократических групп интересовявляется геополитическая и стратегическая значимость регионов. Часто эти условия совпадают, поэтому существования большой части проектов, связанных именно с освоением и разработкой новых месторождений полезных ископаемых, отрицать не приходиться ${ }^{3}$.

\section{Примерами инвестиционных проектов,} затрагивающих сырьевые регионы, могут служитьследующие: проект «комплексного развития Южной Якутии», полигон ТБО, г. Новокузнецк, площадка «Маркино» (Кемеровская область) ${ }^{4}$, строительство Металлургического завода по производству сортового проката (Тюменская область) ${ }^{5}$. Все перечисленные проекты, так или иначе, курируются крупным бизнесом. Например, проект в Тюменской области напрямую ведет

\footnotetext{
2 Закон для инвестора//Портал о лоббизме lobbying.ru. http://www.lobbying.ru/content/sections/articleid_8055 linkid_51.html

${ }^{3}$ Кузнецова О.В. Федеральная региональная политика в России: современное состояние и перспективы // Региональные исследования. № 1, 2009.

${ }^{4}$ Паспорт инвестпроекта. Ассоциация лесопользователей. http://www.alppp.ru/law/hozjajstvennaja-dejatelnost/ stroitelstvo/7/rasporjazhenie-pravitelstva-rf-ot-03-092009-1284-r.html, сайт «Государственно-частное партнерство», http://www.pppi.ru/regions

${ }^{5}$ Металлургический завод в Тюмени достроят в складчину. Информационно-аналитический центр «Минерал». 27.11.2009. http://www.mineral.ru/News/38990.html
} 
УГМК. Самым крупным проектом из тех, которые интересны нефтегазовым корпорациям и ведутся на территории сырьевых регионов, является многоцелевой проект «Урал Промышленный- Урал Полярный».

Примером более специализированных инвестиционных проектов, выгодных компаниям с сырьевой специализацией, могут служить следующие инфраструктурные объекты: Белкомур, Баренцкомур, Полярная, Трансконтинентальная, Северо-Сибирская, Амуро-Якутская- все это планируемые железные дороги, находящиеся на стадии утверждения ${ }^{1}$. Все перечисленные проекты финансируются из Инвестиционного Фонда РФ и реализуются на принципах государственно-частного партнерства. Тот факт, что стадия реализации проектов еще не наступила, делает борьбу корпораций за утверждение данных проектов особенно актуальной. Во всех перечисленных проектах, помимо компаний сырьевой специализации, заинтересована госкомпания РАО «РЖД», имеющая уже существующие участки дорог, на базе которых планируется построить вышеперечисленные магистрали².

Таким образом, крупные проекты, ведущиеся в рамках осуществления региональной политики, реализуются в основном за Уралом. Это преимущественно проекты добывающих отраслей и производств по первичной переработке сырья. Так, вышеперечисленные проекты и программы, затрагивающие сырьевые регионы, напрямую связаны с разработкой природных ресурсов и улучшением инфраструктуры вокруг ценных

\footnotetext{
${ }^{1}$ Княгин В. Государственная политика регионального развития в России. Журнал «Русский Архипелаг». 2001 г. http://www.archipelag.ru/authors/knyginin/?library=1147

${ }^{2}$ Северо-Сибирская история. «Эксперт Сибирь» № 16 (205) /21 апр. 2008. http://expert.ru/siberia/2008/16/ zhelezhnye_dorogi/
}

месторождений. В целом, такое масштабное развитие инфраструктуры Урала и Сибири вызвано прогнозами о том, что сырьевые отрасли в скором времени достигнут таких масштабов, с которыми существующие Транссиб и БАМ перестанут справляться³ Следовательно, для сырьевых компаний продвижение вышеперечисленных проектов крайне необходимо.

Основное участие бизнеса в региональной политике заключается в том, что проходят не все проекты, а только «самые нужные». Влияние на отбор софинансируемых государством проектов как раз и подразумевает под собой участие крупного бизнеса в формировании и реализации региональной политики Российской Федерации. В этой борьбе существует не только внутренняя конкуренция между разными бизнес-акторами, но и внутренняя кооперация. Помимо ФПГ, присутствующих в регионах сырьевой добычи, в инвестпроектах заинтересованы и другие крупные федеральные компании (например, «РЖД», «ВСМПО-Ависма» и др.) Следовательно, присутствие крупного экономического актора в регионе еще не определяет его участия в проектах региональной политики. ФПГ, не присутствующие в сырьевом регионе, так же участвуют в формировании и реализации региональных проектов федеральной власти, затрагивающих сырьевые территории ${ }^{4}$.

Третий инструмент региональной политики, в котором заложена возможность крупного федерального бизнеса реализовывать свои интересы,- открытые экономи-

\footnotetext{
${ }^{3}$ Северо-Сибирская история. «Эксперт Сибирь» № 16 (205) /21 апр. 2008. http://expert.ru/siberia/2008/16/ zhelezhnye_dorogi/

${ }^{4}$ Типология регионов Независимого института социальной политики. http://www.socpol.ru/atlas/ typology/index.shtml
} 
ческие зоны (ОЭ3). Этот инструмент мы будем учитывать в меньшей степени, т.к. воспользоваться им с целью развития сырьевых отраслей стало сложнее. ОЭЗ были более актуальным феноменом для 90-х и начала нулевых, когда они использовались как внутренние офшорные зоныи давали бизнесу возможность получать значительные налоговые послабления. Свободные экономические зоны (более ранний аналог ОЭЗ) существовали с 1997 г., позжес принятием соответствующего Ф3 (2005 г.) начала функционировать их современная форма-открытые экономические зоны. Внутренние офшоры, которые действовали под прикрытием СЭЗ, были ликвидированы в 2004 г.

Определенного рода исключением является только ОЭЗ в г. Томск ${ }^{1}$, в которой одним из резидентов состоитхолдинг «Сибур»-- ранее составная часть ФПГ «Газпром», а ныне принадлежащий «Новатэку» (Л. Михельсон $57 \%$, Г. Тимченко 37\%). Все же ОЭЗ в Томске носит скорее инновационный и высокотехнологичный характер, нежелинапоминает офшор для сырьевых компаний как в случае с Чукоткой. Правда, в последнее время в связи с возвращением идеи о создании корпорации по развитию Дальнего Востока была поднята мысль о введении ОЭЗ для дальневосточных территорий. Следовательно, потенциал в этом инструменте федеральной региональной политике все еще сохранен.

В итоге заключим, что федеральные компании определенно участвуют в федеральной региональной политике и делают это для реализации своих корпоративных интересов. Основное внимание при таком участии илидаже воздействии на федераль-

${ }^{1}$ Особая экономическая зона в г. Томск //Особые экономические зоны в российской экономике: Учебно-научный комплекс для магистров/ Под ред. Каширина В.В., Сысоева А.П.-М.: МАКС Пресс, 2012. ную региональную политику сосредоточенно на сырьевых регионах.

На практике участие ФПГ в региональной политике в отношении сырьевых регионов проявлялось в использовании трех вышеперечисленных инструментов и территориально совпало с тремя перспективными для бизнесарегиональными направлениями. Участие бизнес-акторов нашей репрезентативной группы в формировании региональной политики локализовалось только в области сырьевых регионов. Таким образом, роль крупного бизнеса сводится к формированию региональной политики именно в отношении регионов этой группы ${ }^{2}$.

В ходе проведенного исследования были установлены: 1) зависимость ФПГ от государственной власти и 2) их совместная заинтересованность в сырьевых регионах. Из этих двух обстоятельств во многом складывается характер влияния бизнес-групп на формирование региональнойполитики. Потребности крупного бизнеса в собственном присутствии на территориях сырьевых регионов, в собственном экономическом развитии и наращивании капитала рождают для него необходимостьучаствовать в государственной региональной политике. Зависимость от государства и срощенность с ним дают финпромгруппам возможностьучаствовать в региональной политике. Таким образом, эти два обстоятельства определяют участие федеральных компаний в региональной политике российского государства. При этом ролькрупного бизнеса преимущественно сводится к формированию региональной политики в отношении регионов сырьевой группы. Технические возможности для участия бизнес-групп представлены в виде

${ }^{2}$ Северо-Сибирская история. «Эксперт Сибирь» № 16 (205) /21 апр. 2008. http://expert.ru/siberia/2008/16/ zhelezhnye_dorogi/ 
официальных инструментов региональной политики- проведении федеральных целевых программ, реализации инвестпроектов на основе государственно-частного партнерства, лоббировании введения ОЭЗ на территориях сырьевых регионов. Неофициальные инструменты участия ФПГ в региональной политике остались в представленном исследовании менее изученными.

Необходимо сделать ряд замечаний относительно самих сырьевых регионов. В проделанном исследовании роль сырьевых регионов как политического актораносила явно пассивный характер. В реальности в рамках федеральной региональной политики роль регионального уровня может быть гораздо более явной. Отчасти это заметно на примере проекта «Урал ПромышленныйУрал Полярный». Тем не менее, в данном исследовании основной акцент былпоставлен на сильных, но теневых и политических акторах-крупнейших российских компаниях сырьевой направленности. Их роль проявилась в скрытом, но сильном влиянии на региональный уровеньс большим потенциалом к росту.

Достаточно очевидно, что на этапе 2004-2012 гг. в треугольнике «власть-бизнес-сырьевые регионы» последняя сторона является скорее частью федеральной системы исполнительной власти. Финпромгруппы в этом треугольнике сильный, но теневой и управляемый политический актор. А самое главное часть совокупности бизнес-акторов частично включена в государственную систему: как за счет официальных механизмов (присутствие членов правительства в составе советов директоров компаний), так и за счет неофициальных механизмов (личных связей). Важной чертой этого крупного бизнеса является то, что он в какой-то степени, своей некоторой частью является оборотной стороной самого сильного и влиятельного в треугольнике актора- государства. В этой связи корпорации дифференцированы и их роли в федеральной региональной политике в отношении сырьевых регионов так же разняться: некоторые в большей степени связаны с федеральной исполнительной властью, некоторые- с региональной ${ }^{1}$.

Однако, реальная жизнь страны протекает не в высоких кабинетах и офисах огромных небоскребов, она протекает «на земле». В высоких кабинетах все спланировать и продумать не получается, поэтому потенциал к участию в формировании региональной политики у регионов значительный. При изменении политической системы может произойти повышение статуса региона как участника ФРП. На данном же этапе в связи с региональным уровнем возникает следующий актуальный вопрос: какой эффект оказывают взаимоотношения власти и крупного бизнеса по поводу владения природными ресурсами на сами регионы, в которых ведется добыча и на их население? Является ли этот эффект положительным? Положительный эффект для регионов может проявляться только в «социальной ответственности» бизнеса, на которой настаивает президент. Второй момент: положительное восприятие, осталось, например, у жителей Чукотки после переназначения Абрамовича на губернаторский пост. Тогда новый губернатор был призван вкладывать деньги в регион и привлекать туда иностранные инвестиции. Немногочисленные жители Чукотского АО были довольны.

В реальности негативный эффект для сырьевых регионов пока очевиднее, чем положительный. Постулат классической экономической теории гласит: экспансия труда, ка-

\footnotetext{
${ }^{1}$ Типологии регионов для целей региональной политики: учеб. пособие/Н.А. Ермакова, А. Т. Калоева.- СПб.: Изд-во СПбГУЭФ, 2011.
} 
питалов и товара в регионы, где преобладают группы традиционной ориентации, должна привести к снижению межрегионального экономического неравенства. Периферия за счет этого имеет шанс интегрироваться с центром ${ }^{1}$. Иными словами, при осуществлении региональных проектов на периферийных территориях региональное неравенство будет сокращаться. Однако, практическое наблюдение за политической и экономической ситуацией заставляет нас тяготеть к теории внутреннего колониализма, при котором центральная «метрополия» доминирует над периферией и отводит ее обществам лишь роль проводников легитимации и стабилизации существующего режима.

Внутренний колониализм суть аналог заморского колониализма. Особенность его состоит в том, что происходит интенсификация контактов периферии с центром. Например, в нашем случае-осуществление масштабных макрорегиональных проектов. Однако, периферия от такого взаимодействия в своем развитии не выигрывает, а теряет. В связи с преобразованиями в региональной политики в 2000-х регионы, особенно сырьевые, стали получать от своего природного потенциала на собственное развитие гораздо меньше, чем раньше.

Экономическое подчинение сырьевых регионов центру в духе внутреннего колониализма закреплялось в 2000-е годы политическими мерами. В этом случае большинству бизнес-акторов, возможно, выгодна монолитная сильная власть в цуентре, при которой им легче удерживать свои ведущуие позиции в cырьевых регионах. Негативная сторона привязанности бизнеса к федеральной власти заключается в том, что в своих

\footnotetext{
${ }^{1}$ Майкл Хэчтер. Внутренний колониализм// Этнос и политика: хрестоматия / Авт.- сост. А. А. Празаускас.М.: Изд-во УРАО, 2000.
}

политических амбициях финпромгруппам нельзя выходить на федеральный уровень, т. к. это противоречит их собственным экономическим интересам (твои активы перераспределят, если не будешь лояльным режиму).Тогда крупный бизнес может удовлетворить эти амбиции реализуя себя на региональном уровне. А значит, реформирование регионального избирательного законодательства (в плане увеличения мажоритарных мандатов в региональных заксобраниях и возвращениявыборов губернаторов), возможно, станет компромиссом не только между властью и протестным населением российских городов-миллионников, но так же между властью и бизнесом. Такой компромисс может быть необходимым, т.к. не весь крупный бизнес лично обязан нынешнему президенту. Даже те, кто обязан, могут в будущем нарушить монолитность и влиятельность правящего режима. К настоящему моменту мы уже видимдва противоборствующих вектора (государственников и приватизаторов).Как писал Майкл Хечтер«модель внутреннего колониализма может объяснить причины отсталости индустриальных обществ (читаем- сырьевых регионов) и кажущейся неустойчивости политической интеграции». Таким образом, региональная политика может быть показателем, как степени консолидации элит, так и степени недовольства сырьевых регионов.

Роль крупного бизнеса в формировании региональной политики государства, проводимой в отношении сырьевых регионов, в будущем будет зависеть от расстановки политических сил и степени консолидации путинского режима. Следовательно, сырьевые компании в своих региональных стратегиях зависимы не только от внешнеэкономической конъюнктуры, но и от внутриполитической конъюнктуры. Прогноз в отношении роли крупногобизнеса в региональной полити- 
ке в будущем зависим от электоральных циклов. Путин как гарант современного политического режима будет обеспечивать участие бизнес-акторов в региональной политике. Участие в том виде, в котором оно проявляется сейчас. В дальнейшем возможно изменение состава экономических акторов, может произойти усиление влиятельности государственных компаний в целом и в региональной политике в частности. Тенденция к этому прослеживается уже сейчас. Так что система государственного капитализ-

\section{Библиография}

1. Henry Hale and Ivan Kurilla, Россия «двухтысячных»: Стереоскопический взгляд (Russia in the 200 0s: A Stereoscopic View), Planeta, 2011.

2. Rostislav Turovsky The Representation of Business Elites in Regional Politics: Etatism, Elitism and Clientelism, // Federalism and Local Politics in Russia: Routledge. 2008

3. Афанасьев М.Н., Клиентелизм и российская государственность.--М.: Московский общественный научный фонд, 2000

4. Белкомур: когда благие намерения превратятся в дорогу. РБК. 12.02.2013. http://top.rbc.ru/ economics/12/02/2013/844689.shtm1

5. Власть, бизнес, общество в регионах: неправильный треугольник/ под редакцией Н. Петрова и А. Титкова; Моск. Центр Карнеги.- М.: РОССПЭН, 2010

6. Гончаров Д. В. Структура территориальной политики России. Полис. № 32012

7. Горшенина Е. В. Региональные экономические исследования: теория и практика. Монография.— Тверь. Тверской ма, устоявшаяся в современной России, в среднесрочной перспективе будет только укрепляться.Сырьевая направленность воздействия компаний, работающих в сырьевом секторе на региональную политику останется неизменной до тех пор, пока не поменяется структура российской экономики. В настоящее время такие изменения предвидеть сложно, хотя часть ФПГ, например«Альфа групп», «Ренова», «АФК система»продолжают переводить свое внимание с сырья на более высокотехнологичные сферы.

гос. ун-т, 2009, http://cyberleninka.ru/ article/n/problemy-tipologii-regionovsubektov-rf, С. 8 и другие.

8. Закон для инвестора//Портал о лоббизмe lobbying.ru. http://www.lobbying.ru/ content/sections/articleid_8055_linkid_51. html

9. Зудин А. Государство и бизнес в России: эволюция взаимоотношений.— «Неприкосновенный запас», № 6 (50), 2006.

10. Зудин А. Ю. Распределение источников влияния на принятие властных решений в современной России// Элиты и общество в сравнительном измерении: сб. ст. под ред. Гаман-Голутвиной О.В.- М.: РОССПЭН, 2011.

11. Княгин В. Государственная политика регионального развития в России. Журнал «Русский Архипелаг». 2001 г. http://www.archipelag.ru/authors/ knyginin/?library $=1147$

12. Костин В.И., Костина А. В. Национальная безопасность современной России: Экономические и социокультурные аспекты.- М.: «Либроком», 2013.

13. Кочетков А. П. Корпоративные элиты.- М: РОССПЭН 2012. 
14. Крыштановская О.В. Российская элита и бизнес// Трансформация российской элиты: 1981-2003 гг. дис. д.с.н. 2003.

15. Кузнецова О.В. Основы региональной политики: учебное пособие: М.: Географический факультет МГУ, 2012.

16. Кузнецова О. В. Федеральная региональная политика в России: современное состояние и перспективы // Региональные исследования. № 1, 2009.

17. Майкл Хэчтер. Внутренний колониализм// Этнос и политика: хрестоматия / Авт.- сост. А. А. Празаускас.- М.: Изд-во УРАО, 2000.

18. Макаркин А. В. Политико-экономические кланы современной России. М.: ЦПТ, 2003.

19. Металлургический завод в Тюмени достроят в складчину. Информационноаналитический центр «Минерал». 27.11.2009. http://www.mineral.ru/ News/38990.html

20. Министерство регионального развития. Типология социально-экономического развития субъектов Российской Федерации. http://archive.minregion.ru/ WorkItems/NewsItem.aspx? NewsID=492;

21. Минченко консалтинг. Доклад «Политбюро 2.0 и большое правительство», август 2012 г.; Доклад «Политбюро 2.0» накануне перезагрузки элитных групп. Январь 2013 г.

22. Норт Д. Институты, институциональные изменения и функционирование экономики.--М.: Фонд экономической книги «НАЧАЛА», 1997

23. Особая экономическая зона в г. Томск //Особые экономические зоны в российской экономике: Учебно-научный комплекс для магистров/ Под ред. Каширина В. В., Сысоева А. П.- М.: МАКС Пресс, 2012.

24. Официальный сайт «Федеральные це- левые программы России», http://fcp. economy.gov.ru/cgi-bin/cis/fcp.cgi/Fcp/ ViewFcp/View/2012/232/

25. Официальный сайт компании «Железные дороги Якутии», http://www. rw-y.ru/

26. Павроз А. В. Группы интересов и лоббизм в политике: Учебное пособие. СПб.: Изд-во С.- Петерб. ун-та, 2006.

27. Паспорт инвестпроекта. Ассоциация лесопользователей. http://www.alppp. ru/law/hozjajstvennaja-dejatelnost/ stroitelstvo/7/rasporjazhenie-pravitelstvarf-ot-03-09-2009--1284-r.html, сайт «Государственно-частное партнерство», http://www.pppi.ru/regions

28. Перегудов С. П. Политическая система России в мировом контексте: институты и механизмы взаимодействия. М.: РОССПЭН, 2011.

29. Путин В. В. Быть сильными: Гарантии национальной безопасности для России.- М.: Едиториал УРСС, 2012.

30. Путин В. В. Послание Федеральному Собранию 2012. президент.рф.

31. Северо-Сибирская история. «Эксперт Сибирь» № 16 (205) /21 апр. 2008. http:// expert.ru/siberia/2008/16/zhelezhnye_dorogi/

32. Типологии регионов для целей региональной политики: учеб. пособие/Н.А. Ермакова, А. Т. Калоева.- СПб.: Издво СПбГУЭФ, 2011.

33. Типология регионов Независимого института социальной политики. http:// www.socpol.ru/atlas/typology/index.shtml;

34. Хархордин О. Основные понятия российской политики. М.: Новое литературное обозрение, 2011.

35. Яковлев А. А. В поисках новой социальной базы, или Почему российская власть меняет отношение к бизнесу.// Общественные науки и современность, № 2, 2013 


\section{References (transliterated)}

1. Henry Hale and Ivan Kurilla, Rossiya «dvukhtysyachnykh»: Stereoskopicheskii vzglyad (Russia in the 200 0s: A Stereoscopic View), Planeta, 2011.

2. Rostislav Turovsky The Representation of Business Elites in Regional Politics: Etatism, Elitism and Clientelism, // Federalism and Local Politics in Russia: Routledge. 2008

3. Afanas'ev M.N., Klientelizm i rossiiskaya gosudarstvennost'.--M.: Moskovskii obshchestvennyi nauchnyi fond, 2000

4. Belkomur: kogda blagie namereniya prevratyatsya $\mathrm{v}$ dorogu. RBK. 12.02.2013. http://top.rbc.ru/ economics/12/02/2013/844689.shtml

5. Vlast', biznes, obshchestvo $\mathrm{v}$ regionakh: nepravil'nyi treugol'nik/ pod redaktsiei N. Petrova i A. Titkova; Mosk. Tsentr Karnegi.- M.: ROSSPEN, 2010

6. Goncharov D. V. Struktura territorial'noi politiki Rossii. Polis. № 32012

7. Gorshenina E. V. Regional'nye ekonomicheskie issledovaniya: teoriya i praktika. Monografiya.- - Tver'. Tverskoi gos. un-t, 2009, http://cyberleninka.ru/ article/n/problemy-tipologii-regionovsubektov-rf, S. 8 i drugie.

8. Zakon dlya investora//Portal o lobbizme lobbying.ru. http://www.lobbying.ru/content/ sections/articleid_8055_linkid_51.html

9. Zudin A. Gosudarstvo i biznes v Rossii: evolyutsiya vzaimootnoshenii.«Neprikosnovennyi zapas», № 6 (50), 2006.

10. Zudin A. Yu. Raspredelenie istochnikov vliyaniya na prinyatie vlastnykh reshenii v sovremennoi Rossii// Elity i obshchestvo v sravnitel'nom izmerenii: sb. st. pod red. Gaman-Golutvinoi O.V.- M.: ROSSPEN, 2011.
11. Knyagin V. Gosudarstvennaya politika regional'nogo razvitiya $\mathrm{v}$ Rossii. Zhurnal «Russkii Arkhipelag». 2001 g. http://www.archipelag.ru/authors/ knyginin/?library $=1147$

12. Kostin V. I., Kostina A. V. Natsional'naya bezopasnost' sovremennoi Rossii: Ekonomicheskie i sotsiokul'turnye aspekty.- M.: «Librokom», 2013.

13. Kochetkov A.P. Korporativnye elity.- M: ROSSPEN 2012.

14. Kryshtanovskaya O. V. Rossiiskaya elita i biznes// Transformatsiya rossiiskoi elity: 1981-2003gg. dis. d. s.n. 2003.

15. Kuznetsova O. V. Osnovy regional'noi politiki: uchebnoe posobie: M.: Geograficheskii fakul'tet MGU, 2012.

16. Kuznetsova O. V. Federal'naya regional'naya politika v Rossii: sovremennoe sostoyanie i perspektivy // Regional'nye issledovaniya. № 1, 2009.

17. Maikl Khechter. Vnutrennii kolonializm// Etnos i politika: khrestomatiya / Avt.sost. A. A. Prazauskas.- M.: Izd-vo URAO, 2000.

18. Makarkin A. V. Politiko-ekonomicheskie klany sovremennoi Rossii. M.: TsPT, 2003.

19. Metallurgicheskii zavod v Tyumeni dostroyat v skladchinu. Informatsionnoanaliticheskii tsentr «Mineral». 27.11.2009. http://www.mineral.ru/News/38990.html

20. Ministerstvo regional'nogo razvitiya. Tipologiya sotsial'no-ekonomicheskogo razvitiya sub"'ektov Rossiiskoi Federatsii. http://archive.minregion.ru/WorkItems/ NewsItem.aspx? NewsID $=492$;

21. Minchenko konsalting. Doklad «Politbyuro 2.0 i bol'shoe pravitel'stvo», avgust 2012 g.; Doklad «Politbyuro 2.0» nakanune perezagruzki elitnykh grupp. Yanvar' $2013 \mathrm{~g}$.

22. Nort D. Instituty, institutsional'nye izmeneniya i funktsionirovanie 
ekonomiki._-M.: Fond ekonomicheskoi knigi «NAChALA», 1997

23. Osobaya ekonomicheskaya zona v g. Tomsk //Osobye ekonomicheskie zony v rossiiskoi ekonomike: Uchebnonauchnyi kompleks dlya magistrov/ Pod red. Kashirina V. V., Sysoeva A. P.- M.: MAKS Press, 2012.

24. Ofitsial'nyi sait «Federal'nye tselevye programmy Rossii», http://fcp.economy. gov.ru/cgi-bin/cis/fcp.cgi/Fcp/ViewFcp/ View/2012/232/

25. Ofitsial'nyi sait kompanii «Zheleznye dorogi Yakutii», http://www.rw-y.ru/

26. Pavroz A. V. Gruppy interesov i lobbizm v politike: Uchebnoe posobie. SPb.: Izd-vo S.- Peterb. un-ta, 2006.

27. Pasport investproekta. Assotsiatsiya lesopol'zovatelei. http://www.alppp. $\mathrm{ru} /$ law/hozjajstvennaja-dejatelnost/ stroitelstvo/7/rasporjazhenie-pravitelstvarf-ot-03-09-2009--1284-r.html, sait «Gosudarstvenno-chastnoe partnerstvo», http://www.pppi.ru/regions

28. Peregudov S. P. Politicheskaya sistema Rossii v mirovom kontekste: instituty i mekhanizmy vzaimodeistviya. M.: ROSSPEN, 2011.

29. Putin V. V. Byt' sil'nymi: Garantii natsional'noi bezopasnosti dlya Rossii.M.: Editorial URSS, 2012.

30. Putin V. V. Poslanie Federal'nomu Sobraniyu 2012. prezident.rf.

31. Severo-Sibirskaya istoriya. «Ekspert Sibir'» № 16 (205) /21 apr. 2008. http:// expert.ru/siberia/2008/16/zhelezhnye dorogi/

32. Tipologii regionov dlya tselei regional'noi politiki: ucheb. posobie/N.A. Ermakova, A. T. Kaloeva.- SPb.: Izd-vo SPbGUEF, 2011.

33. Tipologiya regionov Nezavisimogo instituta sotsial'noi politiki. http://www. socpol.ru/atlas/typology/index.shtml;

34. Kharkhordin O. Osnovnye ponyatiya rossiiskoi politiki. M.: Novoe literaturnoe obozrenie, 2011.

35. Yakovlev A. A. V poiskakh novoi sotsial'noi bazy, ili Pochemu rossiiskaya vlast' menyaet otnoshenie k biznesu.// Obshchestvennye nauki i sovremennost', № 2, 2013 